\title{
A Brief Chronicle of CD4 as a Biomarker for HIV/AIDS: A Tribute to the Memory of John L. Fahey
}

\author{
Jonathan M. Kagan, ${ }^{a,{ }^{*}}$ Ana M. Sanchez, ${ }^{b}$ Alan Landay, ${ }^{c}$ \& Thomas N. Denny ${ }^{b}$ \\ aDivision of Clinical Research, National Institute of Allergy and Infectious Diseases, National Institutes of Health, \\ United States Department of Health and Human Services, Rockville, MD; bDuke Human Vaccine Institute and \\ Center for HIVIAIDS, Duke University, Durham, NC; 'Rush University Medical Center, Chicago, IL \\ *Address all Correspondence to: Jonathan Kagan PhD, Division of Clinical Research, National Institute of Allergy and Infectious Diseases, \\ National Institutes of Health, United States Department of Health and Human Services, 5601 Fishers Lane, Room 4B40, MSC 9820, Rockville, \\ MD 20892-9820; E-mail: jkagan@niaid.nih.gov
}

\begin{abstract}
Foundational cellular immunology research of the 1960s and 1970s, together with the advent of monoclonal antibodies and flow cytometry, provided the knowledge base and the technological capability that enabled the elucidation of the role of CD4 T cells in HIV infection. Research identifying the sources and magnitude of variation in CD4 measurements, standardized reagents and protocols, and the development of clinical flow cytometers all contributed to the feasibility of widespread CD4 testing. Cohort studies and clinical trials provided the context for establishing the utility of CD4 for prognosis in HIV-infected persons, initial assessment of in vivo antiretroviral drug activity, and as a surrogate marker for clinical outcome in antiretroviral therapeutic trials. Even with sensitive HIV viral load measurement, CD4 cell counting is still utilized in determining antiretroviral therapy eligibility and time to initiate therapy. New point of care technologies are helping both to lower the cost of CD4 testing and enable its use in HIV test and treat programs around the world.
\end{abstract}

KEY WORDS: biomarkers, CD4, HIV/AIDS, immune monitoring, flow cytometry w

ABBREVIATIONS: AIDS: acquired immunodeficiency syndrome; ARV: antiretroviral; CD: cluster of differentiation; CDC: Centers for Disease Control; FDA: U.S. Food and Drug Administration; HIV: human immunodeficiency virus; NIAID: National Institute of Allergy and Infectious Diseases; POC: point of care; UCLA: University of California, Los Angeles; WHO: World Health Organization

\section{INTRODUCTION}

John L. Fahey, our colleague, friend, and mentor, made enduring contributions in the fields of basic and clinical immunology, cancer, and infectious diseases, but perhaps none more important than his findings on HIV/AIDS, beginning with its discovery at UCLA in 1981. Over the ensuing 33 years, his studies of HIV immunopathogenesis and epidemiology (in the United States and internationally) helped reveal the paradoxical nature of HIV infection as a disease of both immune depletion and immune activation, concepts that have informed and helped shape today's approaches to HIV diagnosis, treatment, and prevention. Among his lasting findings were those made as part of the Multicenter AIDS Cohort Study, whose foundational research on the natural history of HIV infection, including CD4 as a marker for HIV disease risk, stands as testament to what can be achieved when rigorous laboratory research is integrated within long-term cohort studies. The narrative to follow traces the history of CD4's discovery and development as a biomarker for HIV/AIDS and is dedicated in John's memory with the intent to offer insights (and possibly lessons learned) for immunologic biomarker and immunopathology research, to which he was so passionately committed.

\section{INITIAL DISCOVERY OF CD4 DEPLETION IN AIDS}

The decade of the 1970s saw rapid advances in understanding of the differentiation, function, and phenotypes of human T-lymphocyte subsets ${ }^{1-5}$ at the cellular level. These discoveries, coupled with the advent of hybridoma technology, ${ }^{6}$ immunofluorescent 
antibodies, ${ }^{7,8}$ and cell-sorting instrumentation, ${ }^{9-14}$ heralded a new era of immune diagnostics and immunopathology research such that the appearance of opportunistic infections and Kaposi's sarcoma in previously healthy gay men in the United States (1979-1981) was rapidly recognized as a cellular immune deficiency and the first human disease to be characterized by the selective loss of a specific $T$ cell subset, namely, CD4+ T-helper/inducer cells. ${ }^{15-17}$

It would be nearly three years (1983-1984) before lymphadenopathy-associated virus/human T-lymphotropic virus type III (LAV/HTLV-III) was discovered as the etiologic agent of AIDS ${ }^{18,19}$ and the CD4 (T4) antigen an essential component of its receptor. ${ }^{20,21}$ Nearly 10 more years elapsed before quantitative measurement of HIV-1 plasma RNA would become widely available in the United States. ${ }^{22-24}$ Meantime, as the numbers of cases of what we now call HIV/AIDS grew, physicians and patients needed access to accurate, reproducible CD4 testing for use in diagnosis and therapeutic monitoring, as well as for use in clinical trials.

\section{DEVELOPING CD4 AS A FEASIBLE TEST FOR THE CLINICAL LAB}

At the time that the first AIDS cases presented in the United States in the early 1980s, relatively few laboratories had the capacity to perform CD4 testing. Pathology laboratories were gaining proficiency in performing antibody-based assays for tumor cell markers (e.g., alpha fetoprotein, carcinoembryonic antigen) on tissue samples using light and immunofluorescence microscopy. As such, some of these laboratories began providing CD4 and CD8 cell enumeration for AIDS patients. Though early cytometers and cell sorters had begun appearing in research laboratories in the 1970s, they were not designed for use in a clinical setting. It was not before the mid-1980s, with the advent of instruments such as Ortho Spectrum III, ${ }^{25}$ the Coulter Epics C and Profile, ${ }^{26,27}$ and the Becton Dickinson FACScan ${ }^{13}$ and widespread commercial availability of fluorescent-dye conjugated monoclonal antibodies to human $\mathrm{T}$ cell subsets, ${ }^{28,29}$ that flow cytometers began to become widespread in clinical laboratories. These new instruments, with their advanced fluidics, optics, detectors, and analytic software, represented a new era for the future of clinical immunophenotyping and made CD4 testing practical and affordable. Yet, the technology alone could not assure quality CD4 measurements for clinical use.

Cytologists, immunologists, and clinicians had good reason to suspect that CD4 measurements, just as most biologic assays, would likely demonstrate not only substantial within-person variation but also variation attributable to the test methods themselves. Substantial differences in CD4 counts obtained by different methods and instruments, in different locations, would compromise not only the accuracy and precision of the measurements, but also diminish the usefulness of CD4 testing in guiding clinical decisions regarding disease staging, therapeutic monitoring, and the potential use of CD4 as a surrogate for clinical endpoints in multicenter therapeutic trials. This forward-looking focus on the quality and reliability of CD4 measurements provided the impetus for Janis Giorgi (recruited by John Fahey to UCLA) ${ }^{30}$ and Fred Valentine (at NYU) ${ }^{31}$ to initiate two of the earliest proficiency testing programs for CD4 measurement. By sending laboratories masked whole blood samples, and collecting, along with the measured CD4 counts and percentages, information about laboratories' hematology results (WBC and differentials, automated versus manual), sample preparation methods, and analytic techniques, these investigators were able to: (i) reveal the often large inter-laboratory variation in CD4 measurement, and (ii) define the contribution of factors including cell separation (versus whole blood), staining methods, washing, fixation, gating, and compensation on the quantitation of CD4 T cells. As a result of this work, CD4 testing methods were standardized to improve quality and reduce both inter- and intra-laboratory variation, laying the groundwork for CD4 testing as a routine clinical laboratory measurement, and to date still the strongest predictor of disease progression and survival in HIV disease. ${ }^{32,33}$ Furthermore, this research provided the data to support several evidence-based guidelines for CD4 immunophenotyping (e.g., NIAID Division of AIDS, CDC, and Clinical Laboratory Standards Institute), which became methodologic standards for good laboratory practice. ${ }^{34-37}$ Importantly, this work also supported the ability of laboratories to 
develop reliable reference ranges for CD4 and other immunophenotypes in adults and children ${ }^{38-40}$ and to evaluate new CD4 measurement technologies. ${ }^{41-43}$ With increased global access to HIV therapy through UNAIDS, PEPFAR, and GFATM, CD4 proficiency testing and quality assurance programs are now widely available throughout much of the developing world and play an important role in supporting CD4-based assessments of patients' HIV disease status, eligibility for antiretroviral therapy, indications for opportunistic infection prophylaxis, and monitoring therapeutic responses. Programs include the U.S.-based NIAID DAIDS Immunology Quality Assessment (IQA) program, ${ }^{44}$ UK-based United Kingdom National External Quality Assessment Service (UKNEQAS), ${ }^{45}$ Canadabased Quality Assessment and Standardization for Immunological Measures (QASI), ${ }^{46}$ South Africabased African Regional External Quality Assessment Scheme, ${ }^{47}$ Brazil-based Qualilab, ${ }^{48}$ and Thailand-based External Quality Assessment Program (EQA). ${ }^{49}$

\section{CD4 AS A MARKER FOR HIV/AIDS}

The observation that a laboratory marker deviates from the reference ("normal") range in association with a disease or condition can often be important in pointing to an underlying pathology. In 1981, the CD4 depletion seen in the early AIDS patients, together with the clinical presentation of opportunistic diseases, were strong indicators that this new disease, whatever the cause, featured profound immune deficiency and/ or dysregulation. With CD4 measurement standardized and widely available, the next steps for clinical immunologists were to determine: (i) if CD4 could be used to stage patients' disease severity to predict clinical outcome independent of treatment; (ii) if CD4 could be used to screen for activity of novel anti-HIV therapies; and (iii) if the magnitude of change in CD4 counts seen with anti-HIV therapy could predict the clinical benefit of a drug, and if so, how well.

\section{A. CD4 as a Prognostic Marker}

Results from the MACS, WITS (Women and Infants Transmission Study) and WIHS (Women's Interagency
Health Study), and other longitudinal cohort studies examining the natural history of HIV disease established the utility of CD4 as a predictor of risk for clinical disease in HIV-infected individuals, independent of treatment, based on its ability to measure the severity of $\mathrm{T}$ helper cell depletion. ${ }^{32,50-52}$ This demonstrated prognostic power of CD4 counts provided the basis early on for the inclusion of CD4 in HIV infection classification systems, ${ }^{53}$ and the CDC AIDS surveillance case definition, ${ }^{54}$ and CD4 remains an element of the U.S. and WHO HIV/AIDS treatment guidelines. ${ }^{55,56}$

\section{B. CD4 as a Marker of Therapeutic Activity}

The earliest phase I/II trials of antiretroviral drugs in HIV-infected people consistently showed that CD4 counts increased in proportion to antiviral activity. ${ }^{57-60}$ This finding was fundamental in supporting the FDA's accelerated approval (1991) of the early nucleoside analog HIV reverse transcriptase inhibitors didanosine (ddI), and zalcitabine (ddC) (1992), and several other anti-HIV drugs including the first protease inhibitor, saquinavir, in $1995 .{ }^{61}$ While quantitative plasma HIV-1 RNA is the now the standard for assessing viral load and antiviral therapeutic activity, there can be discordance between immunologic and virologic responses to antiretroviral therapy. ${ }^{62,63}$ For this reason, CD4 counts still remain an important biologic marker in the context of early-phase trials to evaluate the activity of new anti-HIV therapies.

\section{CD4 as a Surrogate Marker for Clinical Endpoints in Clinical Trials}

The ultimate function for a biomarker is to predict clinical outcome and enable the assessment of efficacy of interventions based on marker values. The more fully the marker value reflects the clinical benefit of an intervention, such as the proportion of treatment effect explained, ${ }^{64,65}$ the greater its validity in substituting for clinical endpoints in efficacy trials. Several analyses have shown that in HIV infection, despite its utility as both a prognostic and antiviral activity marker, CD4 count is a relatively weak surrogate marker of antiretroviral efficacy in that 
the observed increase in CD4 only partially explains the clinical benefit seen in patients. ${ }^{66,67}$ Furthermore, the increased CD4 counts observed in trials of HIV patients undergoing treatment with interleukin-2 were not associated with clinical benefit. ${ }^{68,69}$ This finding reemphasized the need for caution in the interpretation of biomarker changes in the context of different therapies (e.g., antivirals versus immunomodulators) where there may be reason to consider that the intervention may have an effect on the marker independent of mechanism(s) that lead to clinical benefit.

\section{CD4 in Infants and Children}

CD4, like other biomarkers, can vary in its utility in different populations. CD4 counts in children under five are highly variable due to fluctuations in absolute lymphocyte counts. ${ }^{70}$ For this reason, the CD4 percentage is preferred over the CD4 cell count for use in young children ${ }^{71}$ at the time of diagnosis of HIV infection, for monitoring children not on antiretroviral therapy, as well as those on treatment when complete virologic suppression cannot be achieved.

\section{CURRENT STATUS AND FUTURE OF CD4 ENUMERATION IN HIV/AIDS}

The 2013 WHO consolidated antiretroviral (ARV) guidelines recommend viral load testing as the preferred approach to monitoring antiretroviral therapy response as it is more sensitive and can detect treatment failure earlier than CD4 counts and clinical monitoring. ${ }^{55}$ These recommendations are supported by data from multiple trials and observational cohorts showing that HIV-positive patients on antiretroviral therapy whose viral load is well controlled have relatively stable CD4 cell counts. ${ }^{72-76}$ Nonetheless, CD4 cell counting is still recommended for determining ART eligibility and time to initiate therapy. ${ }^{55} \mathrm{In}$ addition, CD4 cell counts are utilized to determine treatment and/or prophylaxis for opportunistic infections such as cryptococcal meningitis, ${ }^{77}$ malaria, and bacterial infections. ${ }^{55}$

CD4 testing by flow cytometry can be cost prohibitive in developing countries with instruments typically priced at $\sim \$ 75 \mathrm{~K}$ or more, and reagents at $\$ 3-\$ 7$ per test depending on testing frequency. ${ }^{78}$ This has generated interest in developing lower-cost point of care (POC) testing options for $\mathrm{CD} 4$ enumeration. The WHO criteria for POC diagnostic tools are defined by the acronym ASSURED: affordable, sensitive, specific, user-friendly, rapid and robust, equipment-free, and deliverable to end users. ${ }^{79}$ Recent studies have demonstrated that CD4 POC testing can reduce loss to follow-up increasing ART initiation rates. ${ }^{80-82}$ For example, implementation of POC testing with the Alere Pima at four primary health clinics in Mozambique reduced the percent of patients lost to follow-up before start of ART from $64 \%$ to $33 \% .{ }^{80}$ Prior to the initiation of the POC testing, blood samples were collected once weekly and sent to a nearby laboratory, and patients had to return to the clinic once results were available. With the implementation of the Alere assay, finger stick blood samples were collected and tested generally on the same day.

There are currently four available POC devices with others in development. Table 1 summarizes information on CD4 POC testing options that are currently available or expected in the future. ${ }^{78} \mathrm{As}$ POC devices are developed they must be compared to reference (e.g., flow cytometry) technologies to determine performance characteristics including bias, precision, misclassifications for treatment decisions, and instrument reporting errors. Peeling et al., ${ }^{83}$ in their recent review of POC testing devices, found a lack of standardized testing schemes and fewer than half of studies included precision analyses. Lessons learned from the history of CD4 flow cytometry, including the importance of internal quality control, standardization, and external quality assurance programs, can play an important role in establishing the acceptability of POC testing for CD4.

\section{AFTERWARD}

Looking back on 40 years of CD4 and HIV/AIDS research, a rather lucid picture and a cohesive story emerges from several lines of both competing and converging research. It is never so obvious, except perhaps in hindsight, if or how the pieces of a large scientific puzzle might all fit together. Exactly how 
TABLE 1: CD4 Point of care (POC) testing devices summary

\begin{tabular}{|c|c|c|c|c|c|}
\hline Name & Status & Technology & $\begin{array}{l}\text { Device } \\
\text { price } \\
\text { (USD) }\end{array}$ & $\begin{array}{l}\text { Test } \\
\text { price } \\
\text { (USD) }\end{array}$ & Key features \\
\hline $\begin{array}{l}\text { Alere Pima } \\
\text { Analyser }\end{array}$ & Available & $\begin{array}{l}\text { Multicolor } \\
\text { fluorescence- } \\
\text { based } \\
\text { instrument }\end{array}$ & $\begin{array}{l}\$ 6500- \\
\$ 12,000\end{array}$ & $\$ 6-\$ 12$ & $\begin{array}{l}\text { Measures absolute CD4 counts, but not } \\
\text { \% CD4 counts } \\
\text { Uses disposable test cartridge with } \\
\text { dried reagents } \\
\text { Powered by traditional power supply, } \\
\text { batter or solar power }\end{array}$ \\
\hline $\begin{array}{l}\text { Partec CyFlow } \\
\text { miniPOC }\end{array}$ & Available & $\begin{array}{l}\text { Flow } \\
\text { cytometry- } \\
\text { based } \\
\text { instrument }\end{array}$ & $\$ 12,000$ & $\$ 4$ & $\begin{array}{l}\text { Measures absolute CD4 counts and } \\
\% \text { CD4 counts } \\
\text { Lyophilized testing reagents } \\
\text { Powered by traditional power supply, } \\
\text { solar charge or portable battery system }\end{array}$ \\
\hline $\begin{array}{l}\text { HumaCount } \\
\text { CD4 NOW }\end{array}$ & Available & $\begin{array}{l}\text { Flow } \\
\text { cytometer and } \\
\text { hematology } \\
\text { analyzer }\end{array}$ & $\$ 25,000$ & $\$ 10$ & $\begin{array}{l}\text { Measures absolute CD4 counts, } \% \text { CD } 4 \\
\text { counts, and hematology } \\
\text { Lyophilized testing reagents requiring } \\
\text { no manual preparation } \\
\text { Powered by traditional power supply, } \\
\text { solar charge or portable battery system }\end{array}$ \\
\hline $\begin{array}{l}\text { BD FACS } \\
\text { Presto }\end{array}$ & Available & $\begin{array}{l}\text { Instrument } \\
\text { based on } \\
\text { fluorescence } \\
\text { imaging and } \\
\text { absorbance } \\
\text { reading }\end{array}$ & $\begin{array}{l}\text { Varies by } \\
\text { country }\end{array}$ & $\begin{array}{l}\text { Varies } \\
\text { by } \\
\text { country }\end{array}$ & $\begin{array}{l}\text { Measures CD4 absolute count, } \% \text { CD4 } \\
\text { and hemoglobin } \\
\text { Lyophilized testing reagents are } \\
\text { provided as a disposable test cartridge } \\
\text { Powered by traditional power supply, } \\
\text { solar charge or portable battery system }\end{array}$ \\
\hline $\begin{array}{l}\text { Millipore } \\
\text { Muse and } \\
\text { Muse Human } \\
\text { CD4 T cell kit }\end{array}$ & $\begin{array}{l}\text { Available for } \\
\text { laboratory } \\
\text { research use } \\
\text { only }\end{array}$ & $\begin{array}{l}\text { Fluorescent- } \\
\text { based } \\
\text { microcapillary } \\
\text { system }\end{array}$ & $\$ 13,000$ & $\$ 4$ & $\begin{array}{l}\text { Measures absolute CD } 4 \text { counts and } \\
\% \mathrm{CD} 4 \text { counts } \\
\text { Millipore is seeking CE-IVD marking } \\
\text { Requires minimal sample preparation } \\
\text { Reagents are stored at } 2-8^{\circ} \mathrm{C}\end{array}$ \\
\hline $\begin{array}{l}\text { VISITECT } \\
\text { CD4 semi- } \\
\text { quantitative } \\
\text { test }\end{array}$ & $\begin{array}{l}\text { In } \\
\text { development }\end{array}$ & $\begin{array}{l}\text { Lateral flow } \\
\text { assay }\end{array}$ & $\begin{array}{l}\text { Optional } \\
\text { reader est. } \\
\$ 1200\end{array}$ & Est. \$2 & $\begin{array}{l}\text { Provides semiquantitative results for } \\
\text { CD4 counts } \\
\text { Disposable lateral flow assay } \\
\text { Optional reader will be made available }\end{array}$ \\
\hline $\begin{array}{l}\text { Daktari CD4 } \\
\text { Counter }\end{array}$ & $\begin{array}{l}\text { In } \\
\text { development }\end{array}$ & $\begin{array}{l}\text { Microfluidic- } \\
\text { based electro- } \\
\text { chemical } \\
\text { sensing }\end{array}$ & Est. $\$ 8000$ & Est. \$9 & $\begin{array}{l}\text { Provides Absolute CD4 counts, but not } \\
\% \text { CD4 counts } \\
\text { Label-free; antibodies required for cell } \\
\text { separation }\end{array}$ \\
\hline $\begin{array}{l}\text { MBio CD4 } \\
\text { System }\end{array}$ & $\begin{array}{l}\text { In } \\
\text { development }\end{array}$ & $\begin{array}{l}\text { Two color } \\
\text { fluorescence } \\
\text { imaging } \\
\text { cytometer }\end{array}$ & $\begin{array}{l}\text { Not } \\
\text { Available }\end{array}$ & $\begin{array}{l}\text { Not } \\
\text { Available }\end{array}$ & $\begin{array}{l}\text { Measures absolute CD4 counts, but not } \\
\% \text { CD4 counts } \\
\text { Uses disposable test cartridge }\end{array}$ \\
\hline
\end{tabular}


John Fahey himself would look back on all of this we cannot be sure. But were he to have reviewed this brief history, we are confident he would have concurred with the telling, and some of us who worked closely with him can probably still hear his timeless and inimitable admonition to "insert the mind," to make use of what we have learned and move the field forward.

\section{ACKNOWELDGMENTS}

The authors gratefully acknowledge the helpful review, comments, and suggestions of John Phair (Northwestern University), Fred Valentine (New York University), Donna Mildvan (Mount Sinai Beth Israel Hospital, New York), Lance Hultin and Patricia Hultin (UCLA), and Howard Shapiro (West Newton). This work was supported in part by Contract No. HHSN272201400014C "Immunology Quality Assessment," and Contract No. HHSN272201000045C, "External Quality Assurance Program Oversight Laboratory," from the National Institute of Allergy and Infectious Diseases, a component of the U.S. National Institutes of Health, U.S. Department of Health and Human Services.

\section{REFERENCES}

1. Cantor H, Shen FW, Boyse EA. Separation of helper T cells from suppressor $\mathrm{T}$ cells expressing different Ly components. II. Activation by antigen: after immunization, antigen-specific suppressor and helper activities are mediated by distinct T-cell subclasses. J Exp Med. 1976;143(6):1382-90.

2. Gershon RK. T cell control of antibody production. Contemp Top Immunobiol. 1974;3:1-40.

3. Chess L, MacDermott RP, Schlossman SF. Immunologic functions of isolated human lymphocyte subpopulations. I. Quantitative isolation of human T and B cells and response to mitogens. J Immunol. 1974;113(4):1113-21.

4. Choi YS, Good RA. Development of chicken lymphoid system. I. Synthesis and secretion of immunoglobulins by chicken lymphoid cells. J Exp Med. 1972;135(5):1133-50.

5. Reinherz EL, Schlossman SF. The differentiation and function of human T lymphocytes. Cell. 1980;19(4):821-7.

6. Kohler G, Milstein C. Continuous cultures of fused cells secreting antibody of predefined specificity. Nature. 1975;256(5517):495-7.
7. Moller G. Demonstration of Mouse Isoantigens at the Cellular Level by the Fluorescent Antibody Technique. J Exp Med. 1961;114(4):415-34.

8. Raff MC. Two distinct populations of peripheral lymphocytes in mice distinguishable by immunofluorescence. Immunology. 1970;19(4):637-50.

9. Dittrich W, Gohde W. [Impulse fluorometry of single cells in suspension]. Zeits Naturforsch B. 1969;24(3):360-1.

10. Herzenberg LA, Sweet RG, Herzenberg LA. Fluorescenceactivated cell sorting. Sci Am. 1976;234(3):108-17.

11. Fulwyler MJ. Electronic separation of biological cells by volume. Science. 1965;150(3698):910-1.

12. Kamentsky LA, Melamed MR. Spectrophotometric cell sorter. Science. 1967;156(3780):1364-5.

13. Shapiro HM. Practical flow cytometry. 3rd ed. New York: Wiley-Liss. 1995.

14. Coulter WH. High speed automatic blood cell counter and size analyzer. Proc Natl Electron Conf. 1956;12:1034-40.

15. Gottlieb MS, Schroff R, Schanker HM, Weisman JD, Fan PT, Wolf RA, Saxon A. Pneumocystis carinii pneumonia and mucosal candidiasis in previously healthy homosexual men: evidence of a new acquired cellular immunodeficiency. N Engl J Med. 1981;305(24):1425-31.

16. Masur H, Michelis MA, Greene JB, Onorato I, Stouwe RA, Holzman RS, Wormser G, Brettman L, Lange M, Murray HW, Cunningham-Rundles S. An outbreak of community-acquired Pneumocystis carinii pneumonia: initial manifestation of cellular immune dysfunction. N Engl J Med. 1981;305(24):1431-8.

17. Siegal FP, Lopez C, Hammer GS, Brown AE, Kornfeld SJ, Gold J, Hassett J, Hirschman SZ, Cunningham-Rundles C, Adelsberg BR, Parham DM, Siegal M, Cunningham-Rundles $\mathrm{S}$, Armstrong D. Severe acquired immunodeficiency in male homosexuals, manifested by chronic perianal ulcerative herpes simplex lesions. N Engl J Med. 1981;305(24):1439-44.

18. Barre-Sinoussi F, Chermann JC, Rey F, Nugeyre MT, Chamaret S, Gruest J, Dauguet C, Axler-Blin C, Vézinet-Brun F, Rouzioux C, Rozenbaum W, Montagnier L. Isolation of a T-lymphotropic retrovirus from a patient at risk for acquired immune deficiency syndrome (AIDS). Science. 1983;220(4599):868-71.

19. Popovic M, Sarngadharan MG, Read E, Gallo RC. Detection, isolation, and continuous production of cytopathic retroviruses (HTLV-III) from patients with AIDS and preAIDS. Science. 1984;224(4648):497-500.

20. Dalgleish AG, Beverley PC, Clapham PR, Crawford DH, Greaves MF, Weiss RA. The CD4 (T4) antigen is an essential component of the receptor for the AIDS retrovirus. Nature. 1984;312(5996):763-7.

21. Klatzmann D, Champagne E, Chamaret S, Gruest J, Guetard D, Hercend T, Gluckman JC, Montagnier L. T-lymphocyte T4 molecule behaves as the receptor for human retrovirus LAV. Nature. 1984;312(5996):767-8.

22. Holodniy M, Katzenstein DA, Sengupta S, Wang AM, Casipit C, Schwartz DH, Konrad M, Groves E, Merigan 
TC. Detection and quantification of human immunodeficiency virus RNA in patient serum by use of the polymerase chain reaction. J Infect Dis. 1991;163(4):862-6.

23. Coombs RW, Henrard DR, Mehaffey WF, Gibson J, Eggert E, Quinn TC, Phillips J. Cell-free plasma human immunodeficiency virus type 1 titer assessed by culture and immunocapture-reverse transcription-polymerase chain reaction. J Clin Microbiol. 1993;31(8):1980-6.

24. Lin HJ, Myers LE, Yen-Lieberman B, Hollinger FB, Henrard D, Hooper CJ, Kokka R, Kwok S, Rasheed S, Vahey $\mathrm{M}$, et al. Multicenter evaluation of quantification methods for plasma human immunodeficiency virus type 1 RNA. J Infect Dis. 1994;170(3):553-62.

25. Hoffman RA, Hansen WP. Immunofluorescent analysis of blood cells by flow cytometry. Int J Immunopharmacol. 1981;3(3):249-54.

26. Leif SB, Leif RC, Auer R. The EPICS C analyzer. An ergometrically designed flow cytometer computer system. Anal Quant Cytol Histol. 1985;7(3):187-91.

27. Beckman Coulter I. History of flow cytometry 2000-2015. Available from: http://www.beckmancoulter.com/wsrportal/wsr/research-and-discovery/products-and-services/ flow-cytometry/history-of-flow-cytometry/index.htm

28. Evans RL, Wall DW, Platsoucas CD, Siegal FP, Fikrig SM, Testa CM, Good RA. Thymus-dependent membrane antigens in man: inhibition of cell-mediated lympholysis by monoclonal antibodies to TH2 antigen. Proc Natl Acad Sci U S A. 1981;78(1):544-8.

29. Reinherz EL, Kung PC, Goldstein G, Schlossman SF. Separation of functional subsets of human $\mathrm{T}$ cells by a monoclonal antibody. Proc Natl Acad Sci U S A. 1979;76(8):4061-5.

30. Giorgi JV, Cheng HL, Margolick JB, Bauer KD, Ferbas J, Waxdal M, Schmid I, Hultin LE, Jackson AL, Park L, et al. Quality control in the flow cytometric measurement of T-lymphocyte subsets: the multicenter AIDS cohort study experience. The Multicenter AIDS Cohort Study Group. Clin Immunol Immunopathol. 1990;55(2):173-86.

31. Paxton H, Kidd P, Landay A, Giorgi J, Flomenberg N, Walker E, Valentine F, Fahey J, Gelman R. Results of the flow cytometry ACTG quality control program: analysis and findings. Clin Immunol Immunopathol. 1989;52(1):68-84.

32. Mellors JW, Munoz A, Giorgi JV, Margolick JB, Tassoni CJ, Gupta P, Kingsley LA, Todd JA, Saah AJ, Detels R, Phair JP, Rinaldo CR Jr. Plasma viral load and CD4+ lymphocytes as prognostic markers of HIV-1 infection. Ann Intern Med. 1997;126(12):946-54.

33. Egger M, May M, Chene G, Phillips AN, Ledergerber B, Dabis F, Costagliola D, D'Arminio Monforte A, de Wolf F, Reiss P, Lundgren JD, Justice AC, Staszewski S, Leport C, Hogg RS, Sabin CA, Gill MJ, Salzberger B, Sterne JA; ART Cohort Collaboration. Prognosis of HIV-1-infected patients starting highly active antiretroviral therapy: a collaborative analysis of prospective studies. Lancet. 2002;360(9327):119-29.
34. Calvelli T, Denny TN, Paxton H, Gelman R, Kagan J. Guideline for flow cytometric immunophenotyping: a report from the National Institute of Allergy and Infectious Diseases, Division of AIDS. Cytometry. 1993;14(7):702-15.

35. Schnizlein-Bick CT, Mandy FF, O'Gorman MR, Paxton H, Nicholson JK, Hultin LE, Gelman RS, Wilkening CL, Livnat D. Use of CD45 gating in three and four-color flow cytometric immunophenotyping: guideline from the National Institute of Allergy and Infectious Diseases, Division of AIDS. Cytometry. 2002;50(2):46-52.

36. Nicholson JK. Immunophenotyping specimens from HIV-infected persons: laboratory guidelines from the Centers for Disease Control and Prevention. Cytometry. 1994;18(1):55-9.

37. Clinical and Laboratory Standards Institute. Enumeration of immunologically defined cell populations by flow cytometry; Approved Guideline. 2nd ed. CLSI document H42-A2. Wayne, PA: Clinical and Laboratory Standards Institute. 2007.

38. Barnett D, Walker B, Landay A, Denny TN. CD4 immunophenotyping in HIV infection. Nat Rev Microbiol. 2008;6(11 Suppl):S7-15.

39. Denny T, Yogev R, Gelman R, Skuza C, Oleske J, Chadwick E, Cheng SC, Connor E. Lymphocyte subsets in healthy children during the first 5 years of life. JAMA. 1992;267(11):1484-8.

40. Giorgi JV. Lymphocyte subset measurements: significance in clinical medicine. In: Rose N, Friedman H, Fahey J, editors. Manual of clinical laboratory immunology. 3rd ed. Washington, DC: ASM Press. 1992; p. 236-46.

41. Schnizlein-Bick CT, Spritzler J, Wilkening CL, Nicholson JK, O'Gorman MR. Evaluation of TruCount absolute-count tubes for determining CD4 and CD8 cell numbers in human immunodeficiency virus-positive adults. Site Investigators and The NIAID DAIDS New Technologies Evaluation Group. Clin Diagnost Lab Immunol. 2000;7(3):336-43.

42. Reimann KA, O'Gorman MR, Spritzler J, Wilkening CL, Sabath DE, Helm K, Campbell DE. Multisite comparison of CD4 and CD8 T-lymphocyte counting by single- versus multiple-platform methodologies: evaluation of Beckman Coulter flow-count fluorospheres and the tetraONE system. The NIAID DAIDS New Technologies Evaluation Group. Clin Diagnost Lab Immunol. 2000;7(3):344-51.

43. Hultin LE, Menendez FA, Hultin PM, Jamieson BD, O’Gorman MR, Borowski L, Matud JL, Denny TN, Margolick JB. Assessing immunophenotyping performance: proficiency-validation for adopting improved flow cytometry methods. Cytometry Part B. 2007;72(4):249-55.

44. Bainbridge J, Wilkening CL, Rountree W, Louzao R, Wong J, Perza N, Garcia A, Denny TN. The Immunology Quality Assessment Proficiency Testing Program for CD3(+)4(+) and CD3(+)8(+) lymphocyte subsets: a ten year review via longitudinal mixed effects modeling. J Immunol Methods. 2014;409:82-90. 
45. Whitby L, Granger V, Storie I, Goodfellow K, Sawle A, Reilly JT, Barnett D. Quality control of CD4+ T-lymphocyte enumeration: results from the last 9 years of the United Kingdom National External Quality Assessment Scheme for Immune Monitoring (1993-2001). Cytometry. 2002;50(2):102-10.

46. Mandy F, Bergeron M, Houle G, Bradley J, Fahey J. Impact of the international program for quality assessment and standardization for immunological measures relevant to HIV/AIDS: QASI. Cytometry. 2002;50(2):111-6.

47. Glencross DK, Janossy G, Coetzee LM, Lawrie D, Aggett HM, Scott LE, Sanne I, McIntyre JA, Stevens W. Largescale affordable PanLeucogated CD4+ testing with proactive internal and external quality assessment: in support of the South African national comprehensive care, treatment and management programme for HIV and AIDS. Cytometry Part B. 2008;74 Suppl 1:S40-51.

48. Qualilab Home Page [cited 201529 January]. Available from: http://www.aids.gov.br/pagina/2012/51659

49. Pobkeeree V, Lerdwana S, Siangphoe U, Noulsri E, Polsrila K, Nookhai S, Pattanapanyasat K. External quality assessment program on CD4+ T-lymphocyte counts for persons with HIV/AIDS in Thailand: history and accomplishments. Asian Pacific J Allergy Immunol. 2009;27(4):225-32.

50. Fahey JL, Taylor JM, Detels R, Hofmann B, Melmed R, Nishanian P, Giorgi JV. The prognostic value of cellular and serologic markers in infection with human immunodeficiency virus type 1. N Engl J Med. 1990;322(3):166-72.

51. Foca M, Moye J, Chu C, Matthews Y, Rich K, Handelsman E, Luzuriaga K, Paul M, Diaz C; Women and Infants Transmission Study. Gender differences in lymphocyte populations, plasma HIV RNA levels, and disease progression in a cohort of children born to women infected with HIV. Pediatrics. 2006;118(1):146-55.

52. Anastos K, Kalish LA, Hessol N, Weiser B, Melnick S, Burns D, Delapenha R, DeHovitz J, Cohen M, Meyer W, Bremer J, Kovacs A. The relative value of CD4 cell count and quantitative HIV-1 RNA in predicting survival in HIV-1-infected women: results of the women's interagency HIV study. Aids. 1999;13(13):1717-26.

53. Redfield RR, Wright DC, Tramont EC. The Walter Reed staging classification for HTLV-III/LAV infection. The New England Journal of Medicine. 1986;314(2):131-2.

54. Centers for Disease C. Revision of the CDC surveillance case definition for acquired immunodeficiency syndrome. Council of State and Territorial Epidemiologists; AIDS Program, Center for Infectious Diseases. MMWR Morbid Mortal Weekly Report. 1987;36 Suppl 1:1S-15S.

55. WHO. Consolidated guidelines on the use of antiretroviral drugs for treatment and preventing HIV infection.2013. Available from: http://apps.who.int/iris/bitstr eam/10665/85321/1/9789241505727_eng.pdf?ua=1

56. Panel on Antiretroviral Guidelines for Adults and Adolescents. Guidelines for the use of antiretroviral agents in HIV-1-infected adults and adolescents November 2014. Available from: http://aidsinfo.nih.gov/contentfiles/ lvguidelines/AdultandAdolescentGL.pdf

57. Volberding PA, Lagakos SW, Koch MA, Pettinelli C, Myers MW, Booth DK, Balfour HH Jr, Reichman RC, Bartlett JA, Hirsch MS, Murphy RL, Hardy WD, Soeiro R, Fischl MA, Bartlett JG, Merigan TC, Hyslop NE, Richman DD, Valentine FT, Corey L, The AIDS Clinical Trials Group of the National Institute of Allergy and Infectious Diseases. Zidovudine in asymptomatic human immunodeficiency virus infection. a controlled trial in persons with fewer than 500 CD4-positive cells per cubic millimeter. N Engl J Med. 1990;322(14):941-9.

58. Fischl MA, Richman DD, Hansen N, Collier AC, Carey JT, Para MF, Hardy WD, Dolin R, Powderly WG, Allan JD, Wong B, Merigan TC, McAuliffe VJ, Hyslop NE, Rhame FS, Balfour HH Jr, Spector SA, Volberding P, Pettinelli C, Anderson J, The AIDS Clinical Trials Group. The safety and efficacy of zidovudine (AZT) in the treatment of subjects with mildly symptomatic human immunodeficiency virus type 1 (HIV) infection. A double-blind, placebocontrolled trial. Ann Intern Med. 1990;112(10):727-37.

59. Jacobson MA, Bacchetti P, Kolokathis A, Chaisson RE, Szabo S, Polsky B, Valainis GT, Mildvan D, Abrams D, Wilber J. Surrogate markers for survival in patients with AIDS and AIDS related complex treated with zidovudine. BMJ. 1991;302(6768):73-8.

60. Yarchoan R, Venzon DJ, Pluda JM, Lietzau J, Wyvill KM, Tsiatis AA, Steinberg SM, Broder S. CD4 count and the risk for death in patients infected with HIV receiving antiretroviral therapy. Ann Intern Med. 1991;115(3):184-9.

61. FDA. FDA-approved HIV Medicines December 2014. Available from: http://aidsinfo.nih.gov/education-materials/ fact-sheets/21/58/fda-approved-hiv-medicines

62. Wood E, Hogg RS, Yip B, Tyndall MW, Sherlock CH, Harrigan RP, O'Shaughnessy MV, Montaner JS. "Discordant" increases in CD4 cell count relative to plasma viral load in a closely followed cohort of patients initiating antiretroviral therapy. J Acquir Immune Defic Syndr. 2002;30(2):159-66.

63. Spritzler J, Mildvan D, Russo A, Asthana D, Livnat D, Schock B, Kagan J, Landay A, Haas DW; Adult AIDS Clinical Trials Group. Can immune markers predict subsequent discordance between immunologic and virologic responses to antiretroviral therapy? Adult AIDS Clinical Trials Group. Clin Infect Dis. 2003;37(4):551-8.

64. De Gruttola V, Fleming T, Lin DY, Coombs R. Perspective: validating surrogate markers--are we being naive? J Infect Dis. 1997;175(2):237-46.

65. Lin DY, Fleming TR, De Gruttola V. Estimating the proportion of treatment effect explained by a surrogate marker. Stat Med. 1997;16(13):1515-27.

66. De Gruttola V, Wulfsohn M, Fischl MA, Tsiatis A. Modeling the relationship between survival and CD4 lymphocytes in patients with AIDS and AIDS-related complex. J Acquir Immune Defic Syndr. 1993;6(4):359-65. 
67. Choi S, Lagakos SW, Schooley RT, Volberding PA. CD4+ lymphocytes are an incomplete surrogate marker for clinical progression in persons with asymptomatic HIV infection taking zidovudine. Ann Intern Med. 1993;118(9):674-80.

68. Group I-ES, Committee SS, Abrams D, Levy Y, Losso MH, Babiker A, Collins G, Cooper DA, Darbyshire J, Emery S, Fox L, Gordin F, Lane HC, Lundgren JD, Mitsuyasu R, Neaton JD, Phillips A, Routy JP, Tambussi G, Wentworth D. Interleukin-2 therapy in patients with HIV infection. N Engl J Med. 2009;361(16):1548-59.

69. Pett SL, Kelleher AD, Emery S. Role of interleukin-2 in patients with HIV infection. Drugs. 2010;70(9):1115-30.

70. O'Gorman MR, Zijenah LS. CD4 T cell measurements in the management of antiretroviral therapy--A review with an emphasis on pediatric HIV-infected patients. Cytometry Part B. 2008;74 Suppl 1:S19-26.

71. Guidelines for the Use of Antiretroviral Agents in Pediatric HIV Infection February 2014. Available from: http://aidsinfo. nih.gov/guidelines $/ \mathrm{html} / 2 /$ pediatric-treatment-guidelines/0\#

72. Girard PM, Nelson M, Mohammed P, Hill A, van Delft Y, Moecklinghoff C. Can we stop CD4+ testing in patients with HIV-1 RNA suppression on antiretroviral treatment? Aids. 2013;27(17):2759-63.

73. Gale HB, Gitterman SR, Hoffman HJ, Gordin FM, Benator DA, Labriola AM, Kan VL. Is frequent CD4+ T-lymphocyte count monitoring necessary for persons with counts $>=300$ cells $/ \mathrm{muL}$ and HIV-1 suppression? Clin Infect Dis. 2013;56(9):1340-3.

74. Phillips AN, Youle M, Lampe F, Sabin CA, Hill A, Ransom D, Gumley H, Loveday C, Lipman M, Johnson M. CD4 cell count changes in individuals with counts above 500 cells $/ \mathrm{mm}$ and viral loads below 50 copies $/ \mathrm{ml}$ on antiretroviral therapy. Aids. 2002;16(7):1073-5.

75. Whitlock GG, Ahmed N, Benn P, Edwards S, Waters L. Stop routine CD4 monitoring in HIV-infected patients with fully suppressed virus and CD $4>=350$ cells $/ \mathrm{ml}$. Clin Infect Dis. 2013;57(2):327-8.
76. Ford N, Stinson K, Davies MA, Cox V, Patten G, Cragg C, Van Cutsem G, Boulle A. Is it safe to drop CD4+ monitoring among virologically suppressed patients: a cohort evaluation from Khayelitsha, South Africa. Aids. 2014;28(14):2003-5.

77. Jarvis JN, Lawn SD, Vogt M, Bangani N, Wood R, Harrison TS. Screening for cryptococcal antigenemia in patients accessing an antiretroviral treatment program in South Africa. Clin Infect Dis. 2009;48(7):856-62.

78. UNITAID. HIV/AIDS diagnostic technology landscape 2014. Available from: http://www.unitaid.eu/images/ marketdynamics/publications/UNITAID-HIV_Diagnostic_Landscape-4th_edition.pdf.

79. Kettler H, Whte $\bar{K}$, Hawkes S. Mapping the landscape of diagnostics for sexually transmitted infections WHO/ TDR. Geneva. 2004.

80. Jani IV, Sitoe NE, Alfai ER, Chongo PL, Quevedo JI, Rocha BM, Lehe JD, Peter TF. Effect of point-of-care CD4 cell count tests on retention of patients and rates of antiretroviral therapy initiation in primary health clinics: an observational cohort study. Lancet. 2011;378(9802):1572-9.

81. Faal M, Naidoo N, Glencross DK, Venter WD, Osih R. Providing immediate CD4 count results at HIV testing improves ART initiation. J Acquir Immune Defic Syndr. 2011;58(3):e54-9.

82. Larson BA, Schnippel K, Ndibongo B, Xulu T, Brennan A, Long L, Fox MP, Rosen S. Rapid point-of-care CD4 testing at mobile HIV testing sites to increase linkage to care: an evaluation of a pilot program in South Africa. J Acquir Immune Defic Syndr. 2012;61(2):e13-7.

83. Peeling RW, Sollis KA, Crowe SM, Landay A, Cheng B, Barnett D, Denny TN, Spira TJ, Stevens WS, Crowley S, Essajee S, Vitoria M, Ford N. CD4 enumeration technologies: a systematic review of test performance for determining eligibility for antiretroviral therapy. PloS One. 2015;10(3):eFet0115019. 
